\title{
External Morphological Characterization of 60-Days Gestation Myocastor coypus (Coypu) Fetuses
}

\author{
Caracterización de la Morfología Externa de Fetos \\ de 60 Días de Gestación de Myocastor coypus (Coipo)
}

Antonio Eduardo Felipe; Patricia Gabriela Masson; Julio Armando Rodríguez \& Ricardo Horacio Alzola

FELIPE, A. E.; MASSON, P. G.; RODRÍGUEZ, J. A. \& ALZOLA, R. H. External morphological characterization of 60-days gestation Myocastor coypus (Coipu) fetuses. Int. J. Morphol., 24(1):71-76, 2006.

SUMMARY: The main objective of this work was to carry out the external morphology characterization of 60-days gestation Myocastor coypus (coypu) fetuses since this stage could be considered a crucial point in the prenatal development in this species. Fourteen fetuses out of three litter were analised. Gestational sacs weighing $3.81 \pm 0.27 \mathrm{~g}$ showed an elliptical shape with the larger axis along the direction of the uterus. The average weight of fetuses was $1.13 \pm 0.19 \mathrm{~g}$, the head-to-tail lenght was $1.99 \pm 0.87 \mathrm{~cm}$, the cephalic lenght was $1.01 \pm 0.37 \mathrm{~cm}$, and the biparietal diameter was $0.63 \pm 0.06 \mathrm{~cm}$. Specimens showed differentiation in corporeal, limbs and tail regions; also showed interdigital membranes, well defined optical vesicles and lateral ear lobe sprouts. Comparative analysis of coypu fetuses and equivalent stages of other mammal species will allow to establish similitudes and differences that would permit to mark particularities in the ontogeny of Myocastor coypus.

KEY WORDS: Fetal morphology; Coypu; Myocastor coypus.

\section{INTRODUCTION}

Coypu (Myocastor coypus) is a neotropical rodent, Suborder Hystricognathi, it is among forty species recommended to be included in international economical and in research and developmental programs. In Latin America coypu, Hydrochaeris hydrochaeris (capibara or carpincho), Agouti paca (paca) and Dasyprocta aguti (agouti) are hystricognaths species of high economical value. Coypu is an annual polyoestrum animal; its oestral cycles have a characteristic great variability, it has been shown (Felipe et al., 2001a) that their average duration is $35.5 \pm 10.8$ days ranging from 20 to 60 days. The number of offsprings was 3.82, with a range of 1 to 12 (Colantoni, 1993).

Currently, the knowledge about the developmental biology of coypu is scarce (Felipe et al., 1999 y 2002); in the case of other hystricognaths, it has been shown a few general data (Roberts \& Perry, 1974). Since it has been reported (Felipe et al., 2001a,b y 2004) information related with diet, mating and general care for captured coypuses, this species could become a new model for the morphological studies of prenatal development. Knowledge of coypu embryology would contribute to make more precise the developmental stages of the samples from wild captures, and also to determine the environmental consequences over gestation. Newson (1966) studied the fetal development time course of coypu and found that between 32-35 to 55 poscoitus (pc) days a gradual increase in the fetal vesicle very likely due to the development of the membranes of the fetus and the surrounding liquids. From 55-60 pc days there was a significant increase in the fetal weight. This seemed to correspond to an inflection or crucial point in the prenatal development since the slop of the increase remained constant until birth. This fact was the base of the objective of the present research oriented to morphologically characterize $M$. coypus of sixty days of gestation.

\section{MATERIAL AND METHOD}

Three sexually mature females of $M$. coypus bonariensis weighing $4.10 \pm 0.33 \mathrm{~kg}$ and $7.2 \pm 0.18$ month 
old, were located in a corral with walls of concrete plates and wired, the floor was of concrete and the corral was roofed. The only male of $4.9 \mathrm{~kg}$ and 9 month old was lodged in a corral next to the one of females. Animals were fed daily with $0.3 \mathrm{~kg}$ of commercial food and had access to water ad libitum. Daily colpocytology was performed according to Felipe et al. (2001a). Once oestrus was detected in a female by colpocytology it was transferred to the male corral. Mating was followed by direct observation and colpocytological sampling $1 \mathrm{~h} \mathrm{pc}$; direct watching and microscopical observation after staining to check the presence of sperms into the vagina (Felipe et al., 2001a). The time of mating was recorded and was taken at the zero time of coitus; the age of fetuses was expressed in postcoitus days (pc days). Pregnant females were sacrificed according the Animal Welfare Acta of Veterinary School of the Center University (Tandil, 2002). Medial laparatomy was the technique used to obtaining complete genital tractus. Each uterine horn was examined to detect fetal or embryonic resorption or fetal death. Fourteen 60-pc days fetuses were collected.

Some parameters were measured in the gestational sacs, placenta and fetuses; those were, weight and size (antero-posterior length, dorso-ventral diameter and width). After opening gestational sacs, placental weight, length and thickness, external morphology qualitative characteristic (color and appearance) were measured and recorded. The umbilical cord was also measured in lenght and medium diameter. Each fetus was examined in order to get the following: 1 ) body shape (head, chest, abdomen, pelvis and limbs subdivisions); 2) presence and location of cephalic structures (ears, eyes, nose, nasal fossas, lips); 3) limbs (position, lenght and presence and number of fingers); 4) macroscopical aspects of genital and perineal areas (penis or vagina and anal opening); 5) organ sprout relief, hair and nails, mammary line or mammary glands; 6) tail lenght, and 7) weight. Regarding body sizes: cephalocaudal lenght (CCL); crown-rump lenght (CRL); cephalic lenght (from occipital bone to the nouse anterior limit, CL) and biparietal diameter. To evaluate fetal membranes its total weight, as well as the weight of the liquid contained inside, and its qualitative characteristics (color and appearence) were recorded (Wintour et al., 1986; Cross, 1998).

The observations were done with stereoscopic lens. Measurements were carried out with a Vernier type caliper. Weighings were done in an electronic scale Kern 770 ( $( \pm 0.1 \mathrm{mg}$.). All values was expressed as mean \pm standard deviation of the mean ( $\mathrm{x} \pm \mathrm{sd}$.) Fetal structures were named according to Nomina Embryologica Veterinaria (1994) and to Nomina Anatomica Veterinaria (1992).

\section{RESULTS}

Gestational sacs. Gestational sacs showed an elliptic shape (Fig. 1A), with the major axis along the uterus. The average weight was $3.81 \pm 0.27 \mathrm{~g}$. Between two gestational sacs, septa or incomplete uterine partitions were observed (Fig. 1B). Morphometrical data of sacs are presented in Table I. A great part of total weight of a gestational sac was the liquid content; fetus and placenta account for the difference (Fig. 2).

Placenta and umbilical cord morphology. Discoidal placentae weighed $0.60 \pm 0.14 \mathrm{~g}$, they have an external unilobular appearance and were red-wine colored. Subplacenta showed an irregular conical shape and had a pink color. Morphometrical data of placenta are shown in Table I. Umbilical cord was rolled up around the body of the fetus; it has a smooth and brilliant surface, it was not so much spiraled, it has a proximal expansion in the insertion with fetus abdomen and ramifications in the zone of insertion with the placenta. The lenght of the cord was $0.99 \pm 0.14 \mathrm{~cm}$ and it had a diameter of $0.18 \pm 0.03 \mathrm{~cm}$.

Table I. Morphometic data of gestational sacs, fetuses and placenta of 60 pc days Myocastor coypus. Values are expressed as x \pm s.d.

\begin{tabular}{ccc}
\hline & Parameter & Values $(\mathrm{cm})$ \\
\hline Gestational sacs & Antero-posterior length & $4.76 \pm 0.3$ \\
& Dorso-ventral diamete r & $2.89 \pm 0.41$ \\
& Width & $1.91 \pm 0.16$ \\
\hline Placenta & Lenght & $1.26 \pm 0.12$ \\
& Width & $1.06 \pm 0.13$ \\
Fetal lengths & Thickness & $0.41 \pm 0.05$ \\
& Cephalic length & $1.01 \pm 0.37$ \\
& Cephalo-caudal lenght & $1.99 \pm 0.87$ \\
& Crown-rump lenght & $1.89 \pm 0.09$ \\
& Biparietal diameter & $0.63 \pm 0.06$ \\
\hline
\end{tabular}

Characteristics of the fetal membranes. Fetal envelopes showed as thin and transparent membranes, its weight was $0.52 \pm 0.11 \mathrm{~g}$. The liquid inside was clear and light amber colored; it weight was $1.51 \pm 0.22 \mathrm{~g}$.

Characteristics of the fetuses. Fetuses weighed $1.13 \pm 0.19$ $\mathrm{g}$ average and were white colored. They body sizes are shown in Table I. Head, chest, abdomen and limbs sprout differentiation were observed at this stage of development (Fig. 3). The head had a $45^{\circ}$ flexure which allowed to visualize in a prominent way the telencephalum and mesencephalum vesicles. Embryonic earlobes (tubercula 

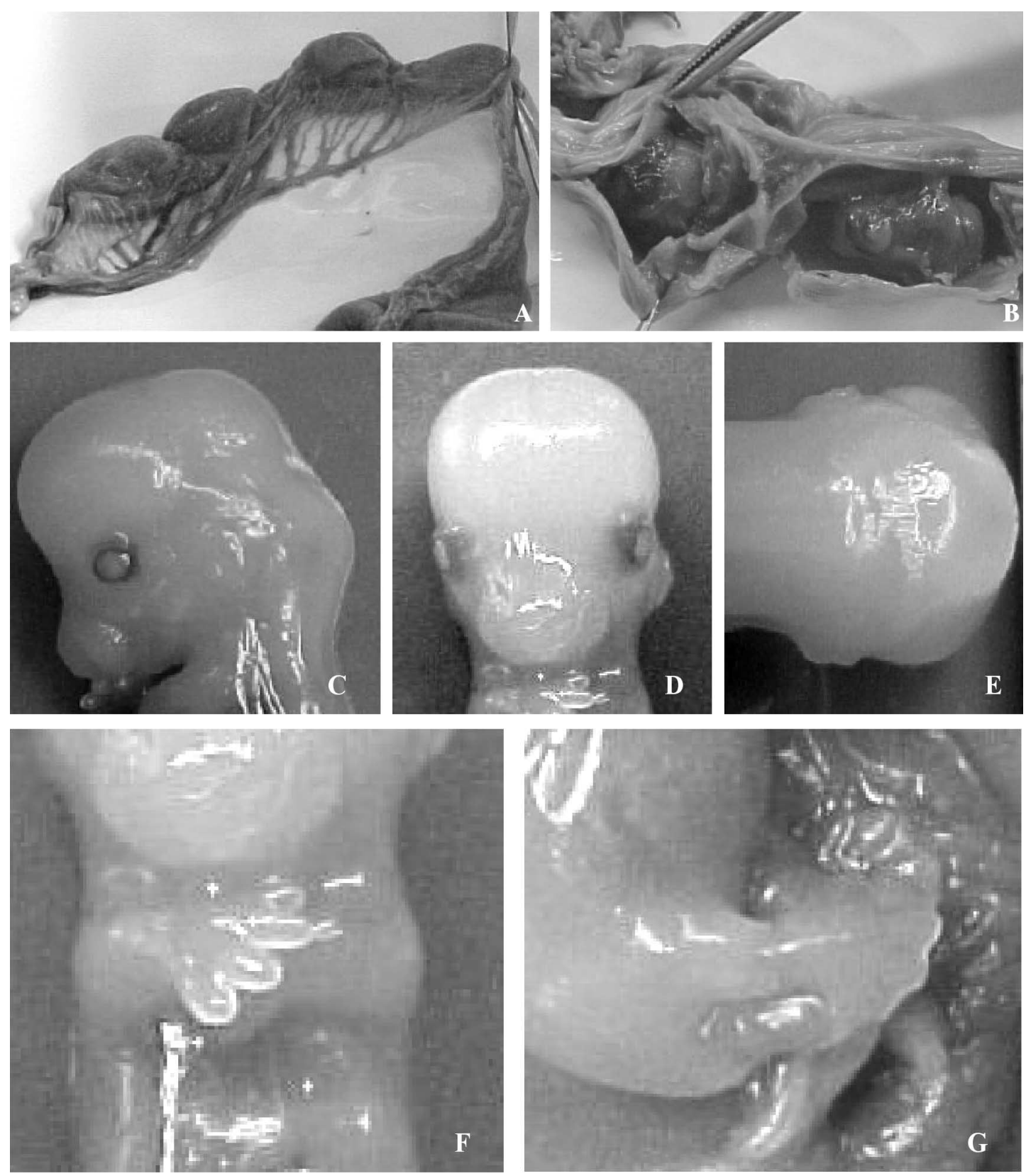

Fig. 1. (A) Uterus horn with four gestational 60 pc days sacs; (B) Opening in uterine wall showing gestagional sacs and uterine septum (2); (C), (D) and (E) Lateral, frontal and dorsal views, respectively, of the cephalic region; (F) Overlaying anterior limbs showing finger separation (3); (G) Posterior limb with an interdigital membrane binding fingers (4). Bars: $1 \mathrm{~cm}$.

auricularia) had a low level of development and located at both craneal sides; they were just at the border of cervical area and in line with optical vesicles (Figs. 1C, 1D and 1E). These showed up clearly on the rostral surface, they had a prominent lens placode and are surrounded by palpebral protuberances (plicae palpebrales). The lips medium area showed a commissure at its dorsal contour. Nasal edges were not prominent. At the dorsal region of chest as well as at the abdominal region, the line of spinal cord was distinguished with a rim at both sides; no clear vestige of vertebra were observed. Anterior and posterior limbs were present in such an arreange that formed right angles with the body axis. Anterior limb sprouts have a lenght of $0.55 \pm 0.04 \mathrm{~cm}$; at this stage of development they showed differentiation into 
forearm, arm and hand with separate fingers (digiti definitivi) (Fig. 1F). Regarding posterior members, they had a lenght of $0.64 \pm 0.04 \mathrm{~cm}$; the foot (pes primitivus) presented an interdigital membrane binding the fingers throughout (digiti primordialis nonseparati con membrana interdigitalis) (Fig. $1 \mathrm{G})$. Skin was transparent without hairy follicles (except in the prominentia nasalis lateralis). Neither heart elevation nor liver prominence were present in the corresponding location, i.e., chest and abdominal areas. Rim of the mammary line were not observed. Genital tubercle and anal rim were observed in the perineal area. Tail was present and its lenght was $0.81 \pm 0.07 \mathrm{~cm}$.

\section{DISCUSSION}

Embryogenesis of a given specimen in any species correlates with a series of continuous changes in a similar manner that prenatal development occurs in the different species (Knospe, 2002; Beaudoin et al., 2003). In spite of accepted similarities, there is a number of embryo classifying systems. For instance, the Nomina Embryologica Veterinaria (1994) establishes 15 stages; the Carnegie system names 23 stages (O’Rahilly, 1972); the Theiler system (1972) considers 27 stages for mice, and Dyban et al. (1975) system establishes 24 stages for laboratory murine rodents and rabbit. In general, embryo and fetal development description in other species were based on stages built over age, corporeal

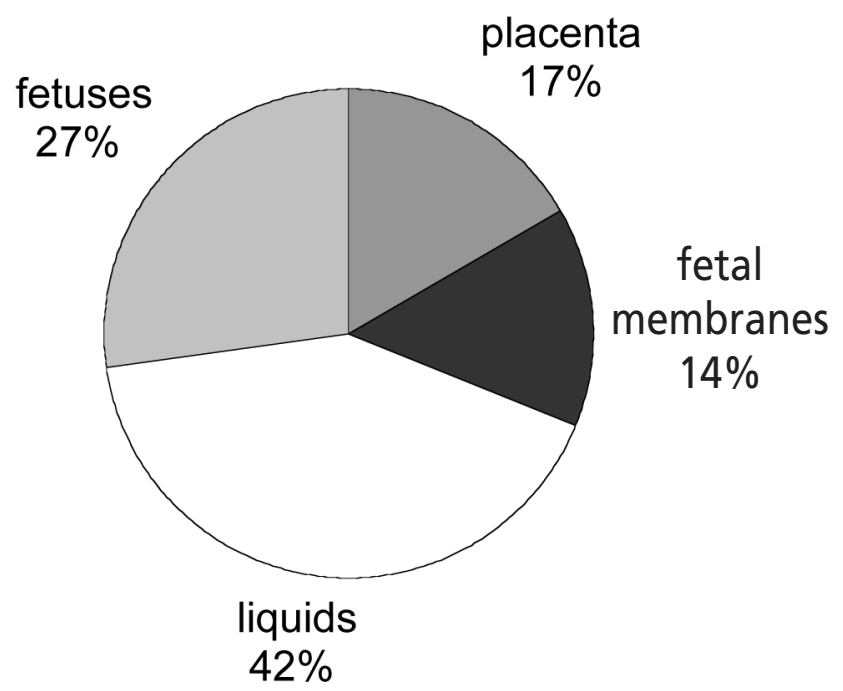

Fig. 2. Percentage of total weight of each component of $60 \mathrm{pc}$ days Myocastor coypus gestational sacs.

changes by gradual differentiation, increase of body size and weight, and overall development of organ systems (Theiler; Knospe; Beaudoin et al.).

Based on the external morphological characteristics of developmental degree, $60 \mathrm{pc}$ days coypu fetuses are alike human fetuses of Streeter's Horizon XIX (LCG 18 mm, 39 \pm 1 days) (Genis Gálvez, 1970) and 19 and 20 Carnegie's stages (Butler \& Juurlink, 1987); this is suggested on the

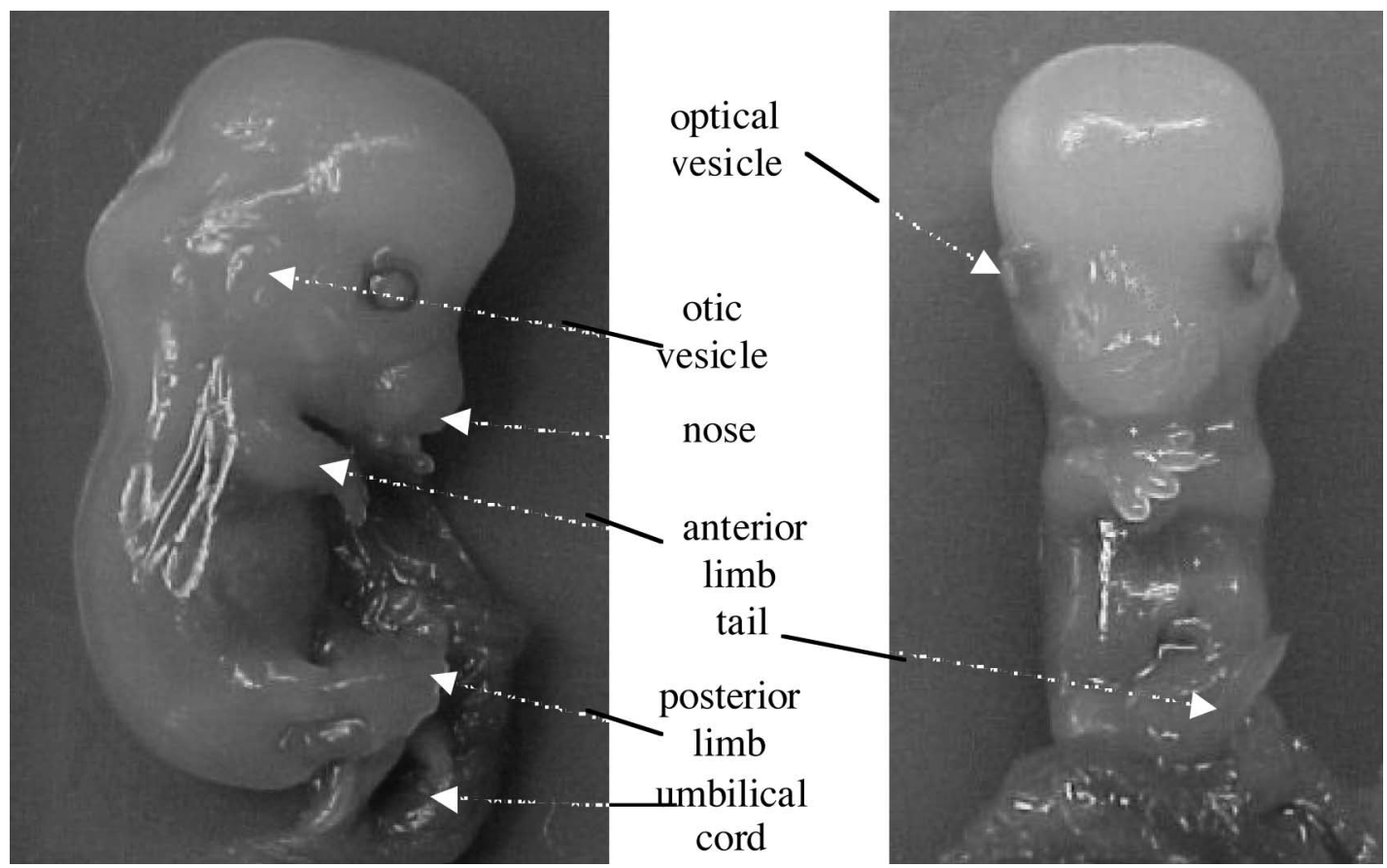

Fig. 3. Lateral and frontal views of $60 \mathrm{pc}$ days fetuses of Myocastor coypus. Bar: $1 \mathrm{~cm}$. 
base of similarities in the development of limbs (presence of fingers on the anterior limbs) and their position (towards the ventromedial line and with a little separation between them); marked relief of eyelids and early presence of earlobe sprouts. Making comparison of coypu fetuses with those of primates like baboon (Papio cynocephalus), are according the observations of Hendrickx (1971) in Horizons XXI (LCG 18$21 \mathrm{~mm}, 43 \pm 1$ days) and XXII (LCG $22.5 \mathrm{~mm} .45 \pm 1$ days), such as limbs position, cephalic structures development degree, presence of fisiologic umbilical hernia, thick eyelids, tragus and antitragus, and superposition toward frontal of the fingers of one hand with the other. In mice, separation of fingers of hands, umbilical hernia, eyes development stage, earlobe and tail correspond to Theiler stage 22 (14 pc days); but differ from that stage because the absence of hairy follicles at pectoral, pelvic and trunk (Davidson \& Baldock, 1998). Taking into account limbs development, coypu fetuses analyzed would correspond to stage 11 of mice limbs development (15 pc days) according to Wanek et al. (1989); there was a complete finger separation of anterior limbs but no differentiation of elbows and knees nor hear foliculi over the members were observed. According to Wanek et al. stage 11 of mice is equivalent to stage 23 of Theiler. However, the presence of hairy follicles in coypu fetuses corresponding to the whiskers makes them more alike to the $13 \mathrm{pc}$ days mice and the remaining external morphological traits to the 14.5 pc days described by Rugh (1969).
Considering the nine levels of development system of Stêrba (1976 and 1995), 60 pc days coypu fetuses would be at level 5. In this level of development fetuses have well defined face, prominence of the mesencephalum, fingers separate in the anterior limb, sprout of earlobes and whiskers follicles at the upper lip making prominence in the epidermal surface. These traits are sheared by rodents like Pitymys subterraneus, Pitymys tatricus and Microtus nirvalis mirhanreini at $14 \mathrm{pc}$ day (67 to $68 \%$ of gestation) (Stêrba, 1976), Clethrionomys glareolus of 14.5 pc days (Mísêk, 2003) and rabbit fetuses of 15.5 and 16.5 pc days (Beaudoin et al.).

According to Nomina Embryologica Veterinaria (1994), 60 pc days coypu would correspond to the periodus labii fissi do to cephalic structures distinction, hand finger differentiation and presence of interdigital membrane at feet (pes primitivus).

Comparisons done of coypu fetuses with equivalent stages of other mammals species would allow us to ascertain the notion, suggested by Mísêk, that it is possible to predict the prenatal development stage of a species knowing the traits of other, regardless the lenght of the period of gestation. Care should be taken with regard of the differences observed and take into account the particularities of the spotted species.

FELIPE, A. E.; MASSON, P. G.; RODRÍGUEZ, J. A. \& ALZOLA, R. H. Caracterización de la morfología externa de fetos de 60 días de gestación de Myocastor coypus (Coipo) fetuses. Int. J. Morphol., 24(1):71-76, 2006.

RESUMEN: El objetivo de este trabajo fue efectuar la caracterización de la morfología externa de fetos de 60 días de gestación en Myocastor coypus (coipo), ya que éstos pueden ser considerados como un punto de inflexión en el desarrollo prenatal de la especie. Se analizaron 14 fetos provenientes de tres camadas. Los sacos gestacionales, cuyo peso fue de $3.81 \pm 0.27 \mathrm{~g}$, mostraron forma elíptica, con su diámetro mayor orientado en paralelo con la dirección de los hemiúteros. El peso medio de los fetos fue de 1.13 \pm 0.19 grs, con una longitud céfalo-caudal de $1.99 \pm 0.87 \mathrm{~cm}$, longitud cefálica de $1.01 \pm 0.37 \mathrm{~cm}$ y un diámetro biparietal de $0.63 \pm$ $0.06 \mathrm{~cm}$. Los especímenes mostraron diferenciación de regiones corporales, extremidades y cola, membranas interdigitales en los miembros posteriores, vesículas ópticas bien definidas y esbozos de pabellones auriculares en posición lateral. El análisis comparativo de los fetos de coipo con estadios equivalentes de otros mamíferos, permitió determinar similitudes y también diferencias que indicarían particularidades de la especie.

PALABRAS CLAVE: Morfología fetal; Coipo; Myocastor coypus.

\section{REFERENCES}

Acta de Bienestar Animal. Facultad de Cs. Veterinarias, UNCPBA, 2002. http://www.vet.unicen.edu.ar/facultad/ bienestaranimal.htm.

Beaudoin, S.; Barbet, P. \& Bargy, F. Developmental stages in the rabbit embryo: guidelines to choose an appropiate experimental model. Fetal. Diagn. Ther., 18:422-7, 2003.
Butler, H. \& Juurlink, B.H.J. An Atlas for Staging Mammalian and Chick Embryos. Boca Ratón, C.R.C. Press Inc., 1987.

Colantoni, L. O. Ecología poblacional de la nutria (Myocastor coypus) en la Provincia de Buenos Aires. Rev. Fauna y Flora Silvestres 1 (1):25, 1993. 
Cross, J.C. Formation of the placenta and extraembryonic membranes. Ann. N. Y. Acad. Sci., 23 (857): 23-32, 1998.

Davidson, D. R. \& Baldock, R.A. The Edinburgh mouse atlas, 1998.

Dyban, A. P.; Puchkov, V.F.; Baranov, V. S.; Samoshkina, N.A. \& Chebotar, J. Laboratory mammals. In: Objects of developmental biology. Nauka, Moscú, 1975. Op. cit. Stêrba, 1975.

Felipe, A., Callejas, S. \& Cabodevila, J. Anatomohistological Characteristics of the ovary of the south american nutria (Myocastor coypus). Anat. Histol. Embryol., 28:89-95, 1999.

Felipe, A.; Cabodevila, J. \& Callejas, S. Characterization of the estrous cycle of the Myocastor coypus (coypu) by means of exfoliative colpocytology. J. Neotrop. Mastozoology, 8 (2):129-37, 2001a.

Felipe, A.; Teruel, M.; Cabodevila, J. \& Callejas, S. Controlled mating in Myocastor coypus (coypu). Scientifur, 25:99-104, 2001b.

Felipe, A.; Teruel, M.; Cabodevila, J. \& Callejas, S. Preimplantational timetable of embryonal development of Myocastor coypus (coypu). Reprod. Nutr. Dev., 42 (1):15-24, 2002.

Felipe, A. E.; Teruel, M. T.; Cabodevila, J. A. \& Callejas, S. S. Morphological aspects of in vivo cleavage in Myocastor coypus (coypu). Anat. Histol. Embryol., 33 (2):75-80, 2004.

Genis Gálvez, J. M. Biología del desarrollo. Ed. Espaxs, Barcelona, 1970.

Hebel, R. \& Stromberg, M.W. Anatomy and embryology of the laboratory rat. Biomed. Verlag, 1985.

Hendrickx, A. G. Embryology of the baboon. Univ. Chicago Press, Chicago, 1971.

Knospe, C. Periods and stages of the prenatal development of the domestic cat. Anat. Histol. Embryol., 31:37-51, 2002.

Mísêk, I. Staging and ageing of mammalian embryos and fetuses according to Sêtìrba. 2003. http://www.iach.cz/ lge/puble.htm.
Newson, R. M. Reproduction in the feral coypu (Myocastor coypus). In: Comparative Biology of Reproduction in Mammals, I. W. Rowlands (ed.) pp 323-34, Academic Press, Londres, 1966.

Nomina Anatomica Veterinaria. $4^{\text {th }}$. Ed. World Association of Veterinary Anatomists, Zurich, Ithaca, Cornell University, 1992.

Nomina Embryologica Veterinaria. $1^{\text {st }}$ Ed. World Association of Veterinary Anatomists, Zurich, Ithaca, Cornell University, 1994.

O’Rahilly, R. Guide to the staging of human embryos. Anat. Anz., 130:556-59, 1972.

Roberts, C.M. \& Perry, J.S. Hystricomorph embryology. Symp. zool. Soc. Lond., 34:333-60. 1974.

Rugh, R. The mouse. Its reproduction and development. Burgess Publ. Co., Minneapolis, 1969.

Stêrba, O. Prenatal development of microtine rodents. Acta Sc. Nat. Brno, 10 (1):1-41, 1976.

Stêrba, O. Staging and ageing of mammalian embryos and fetuses. Acta Vet. Brno 64:83-89, 1995.

Theiler, K. The house mouse. Development and normal stages from fertilization to 4 weeks of age. Springer Verlag, New York, 1972.

Wanek, N.; Muneoka, K.; Holler-Dinsmore, G.; Burton, R. \& Bryant, S.V. A staging system for mouse limb development. J. Experim. Zool., 249:41-9, 1989.

Wintour, E.M.; Laurence, B.M. \& Lingwood, B.E. Anatomy, physiology and pathology of the amniotic and allantoic compartments in sheep and cow. Aust. Vet. J., 63(7): 216-21, 1986.

Correspondence to:

Dr. Antonio E. Felipe

Grupo de Investigaciones Biologicas (GIB),

Area de Cs. Morfológicas, Depto. Cs. Biologicas,

$\mathcal{F} a c . C s$. Veterinarias, $\mathcal{U} \mathcal{N}\left(\mathcal{P B}_{\mathcal{B} A}\right.$,

Tandil

ARGE $\mathcal{E}$ TINA

E-mail:aefelipe@vet.unicen.edu.ar

Received: 28-11-2005 Accepted: 16-01-2006 